\title{
ХАРАКТЕРНІ ОЗНАКИ, ФАКТОРИ І ФОРМИ РЕАЛІЗАЦІЇ ЕКОНОМІЧНИХ ІНТЕРЕСІВ УЧАСНИКІВ РИНКУ ПРОДУКЦЇ̈ ТВАРИННИЦТВА
}

Мета. Мета статті полягає у висвітленні результатів дослідження з визначення характеристик, факторів $і$ форм реалізачії економічних інтересів суб'єктів (учасників) ринку продукиії тваринництва з одночасним розширенням інструментарію вимірювання рівня узгодженості иих інтересів.

Методологія /методика / nidxid. Теоретико-методичною основою дослідження стали діалектичний метод пізнання економічних проиесів, фундаментальні положення сучасної економічної теорії, наукові праці вітчизняних $i$ зарубіжних учених щуодо дослідження сутності й змісту економічних інтересів учасників агропродовольчого ринку. Для досягнення поставленої мети використано системний підхід, методи інституціональної політичної економії, узагальнення, індукиії, дедукиії, аналізу, синтезу та порівняння.

Результати. Досліджено характерні ознаки сучасних економічних інтересів; визначено основні фактори, які призводять до розбалансованості інтересів учасників агропродовольчого ринку; з'ясовано оптимальні форми реалізачї суперечливих інтересів представників ринку продукції твариннищтва; доведено доцільність розиирення інструментів вимірювання рівня задоволеності (узгодженості) економічних інтересів; обтрунтовано важливість формування механізмів взаємодії (співіснування) інтересів $i$ способів оптимального (злагодженого, гармонійного) їх поєднання; запропоновано блоксхему агропродовольчого ланџюга поставок тваринницької продукиії; розраховано розмір отриманої доданої вартості, понесених витрат на персонал та отриманого прибутку (збитку) з розрахунку на одного зайнятого в розрізі видів економічної діяльності таких суб’єктів ринку продукції тваринництва в Украйні: виробники сільськогосподарської продукиї тваринництва, представники оптової торгівлі сільськогосподарською сировиною та живими тваринами, підприємства переробної харчової промисловості (м'ясного та молочного напрямів), учасники оптової та роздрібної торгівлі продуктами харчування.

Оригінальність / наукова новизна. Уперше запропоновано як інструмент кількісного визначення рівня узгодженості економічних інтересів між учасниками ринку продукиії тваринництва розраховувати розміри отриманої доданої вартості, понесених витрат на персонал та отриманого прибутку (збитку) на одного зайнятого в розрізі видів економічної діяльності.

Практична цінність / значущість. Розширення інструментарію визначення рівня узгодженості (задоволеності) економічних інтересів учасників ринку продукції тваринництва може слугувати прийомом кількісного вираження рівня узгодженості економічних інтересів пов'язаних організаційно-технологічним прочесом суб'єктів будьякого ринку.

Ключові слова: економічний інтерес, продукиія тваринництва, агропродовольчий ринок, рівень узгодженості, додана вартість на одного зайнятого, витрати на персонал, 
прибуток (збиток).

\title{
Olha Kravchenko
}

\author{
Kharkiv Petro Vasylenko National Technical University of Agriculture
}

Ukraine

\section{FEATURES, FACTORS AND FORMS OF ECONOMIC INTERESTS' IMPLEMENTATION OF CATTLE PRODUCTS MARKET PARTICIPANTS}

Purpose. The purpose of the article lies in presentation of the research results on definition of features, factors and forms of economic interests' implementation of cattle products market subjects (participants) with simultaneous expansion of instruments for measuring the level of their interests' consistency.

Methodology / approach. The dialectic method for economic processes perception, fundamental provisions of the modern economic theory, scientific works of national and foreign scientists as to studying the essence and content of the economic interests of agrofood market participants became the theoretic and methodic basis for the research. To achieve the goal set we used as follows: system approach, methods of institutional political economy, generalization, induction, deduction, analysis, synthesis and comparison.

Results. Features of modern economic interests were studied; main factors resulting in agrofood market participants interests disequilibrium were determined; purposefulness for expansion of instruments for measuring the level of the economic interests' satisfaction (consistency) was proved; the importance to develop interaction (coexistence) of interests and means of their optimal (agreed, harmonic) connection was substantiated; the flow diagram of agrofood chain for cattle products supply was demonstrated; the amount of value added received was calculated, as well as the expenses for personnel and profit (loss) received per 1 engaged in the context of the economic activity types of the cattle market subjects in Ukraine taken into account: cattle product manufacturers, representatives of wholesale trade in agricultural raw materials and live animals, enterprises of food processing industries (meat and milk), participants of wholesale and retail trade in food products.

Originality / scientific novelty. For the first time, it was proposed, as the instrument for quantitative expression of the level of the economic interests' consistency among the livestock market participants, to calculate the amounts of value added received, as well as the expenses for personnel and profit (loss) received per 1 engaged in the context of the type of economic activity.

Practical value / importance. Expansion of instruments to determine the level of the economic interests' consistency of the cattle products market participants can serve as a means for quantitative expression of the level of the economic interests' consistency of the subjects of any market connected by the organizational-and-technologic process.

Key words: economic interest, cattle product, agrofood market, consistency level, value added per 1 engaged, personnel costs, profit (loss).

Постановка проблеми. У сучасній українській економіці найбільш небезпечними $\epsilon$ протиріччя між національними інтересами країни та корпоративними інтересами; фінансовим сектором економіки та реальним; галузями, що орієнтовані на експорт, і тими, що обслуговують внутрішній ринок; інтересами більшості населення та фінансової олігархії. Ці протиріччя 


\section{Agricultural and Resource Economics}

www.are-journal.com

порушують архітектоніку ринкового господарювання. За відсутності адекватних механізмів їх узгодження на принципах співіснування посилюються процеси дисгармонізації усієї економічної системи, особливо в умовах глобалізації, коли вплив зовнішніх і внутрішніх факторів на функціонування національного господарства країни частіше $є$ негативним. Як наслідок, маємо посилення неформальних відносин між суб'єктами господарювання. За таких умов проблема неузгодженості інтересів учасників ринкових відносин особливо загострюється. Розв'язання проблеми вимагає розуміння, по-перше, факторів i форм реалізації інтересів, по-друге, інструментів вимірювання рівня узгодженості інтересів i пошуку конкретних механізмів гармонізації економічних відносин між учасниками ринку в умовах наявного економічного простору.

Не $є$ виключенням і стан та розвиток економічних відносин у межах агропродовольчого ринку, зокрема, ринку продукції тваринництва. Особливістю зазначеного ринку є задіяність як виробників - кількох галузей національної економіки (сільського господарства, переробної харчової промисловості, оптово-роздрібної торгівлі), як споживачів - населення країни, $\mathrm{i}$ як гаранта продовольчої безпеки - держави. Тому дослідження, спрямовані на окреслення характерних ознак, факторів і форм реалізації економічних інтересів учасників ринку продукції тваринництва в умовах сучасних трансформацій набувають актуальності та значущості.

Аналіз останніх досліджень і публікацій. Значний внесок у розв'язання актуальних проблем теорії та практики реалізації інтересів суб'єктів господарювання зробили такі вітчизняні науковці, як: В. Смєсова (питання теорії та етапів розвитку економічних інтересів і потенційних напрямів їх розвитку) [19]; Н. Тарасевич (питання гносеології, онтології і методології економічних інтересів, класифікації їніх форм і видів) [22]; Н. Новікова (аспекти взаємовпливу та взаємозалежності інститутів та економічних інтересів, механізмів їх державного регулювання) [15]; А. Грищенко та Н. Далевська (площина захисту інтересів національної економіки в процесі глобалізації та інтеграції світового господарства) [6; 7]; Л. Осіпова (узагальнення щодо класифікації та взаємодії інтересів) [16] та багато інших.

Питання узгодження та координації економічних інтересів учасників аграрного ринку в Україні частково представлені в роботах В. Антощенкової [1], В. Гейця [3], Л. Глубіш [4], С. Дем'яненка [8], Т. Зінчук [9], С. Кирилюка [10], І. Кравчук [12], О. Красноруцького [13], М. Маліка [14], Б. Пасхавера [17], О. Шпичака [25], Ю. Лупенка та інших [28], В. Онегіної та інших [29].

Серед сучасних зарубіжних науковців дослідженням питань, пов’язаних із оцінкою рівня задоволеності (узгодженості) інтересів учасників економічних відносин у межах агропродовольчого ринку, займаються P. Canning, A. Weersink та J. Kelly щодо структури «продовольчого долара» США і Канади [26]. Також варто відзначити роботу P. Cucagna та P. D. Goldsmith [27], які визначили розмір частки кожного учасника агропродовольчого ланцюга в 
доданій вартості.

У науковому світі продовжується дискусія щодо об'єктивності та суб'єктивності категорії «інтерес». Більшість думок зводяться до того, що інтереси, як форма вияву потреби, властиві кожному учаснику суспільноекономічних відносин. Крім того, рівень задоволеності інтересів є чинником, що спонукає до суспільних та індивідуальних дій. Підтвердженням зазначеного $\epsilon$ результати критичного аналізу наукових літературних джерел, проведеного Л. Глубіш, згідно з якими науковці ще не дійшли повного порозуміння щодо сутності поняття «інтерес», у тому числі й «інтерес економічний». Узагальнення трактувань дало підстави автору зробити висновок, що в ході економічних відносин економічні інтереси трансформуються в економічні потреби, спонукаючи людей до економічної діяльності для виробництва економічних благ, що мають їх задовольнити [4, с. 22]. Незважаючи на весь науковий доробок, недостатньо дослідженими залишаються питання саме особливостей сучасних форм реалізації економічних інтересів учасників ринку продукції тваринництва та їх вимірювання в контексті досягнення стійкого інклюзивного, в тому числі соціально-економічного, розвитку країни, зокрема сільських територій, на яких проживає третина населення.

Мета статті полягає у висвітленні результатів дослідження з визначення характеристик, факторів і форм реалізації економічних інтересів суб'єктів (учасників) ринку продукції тваринництва 3 одночасним розширенням інструментарію вимірювання рівня узгодженості цих інтересів.

Виклад основного матеріалу дослідження. Необхідність задовольняти потреби людей породжує економічний інтерес, який є об'єктивною категорією та рушійною силою дій окремої людини, колективу та всього суспільства для досягнення певної мети. В умовах ринкової економіки саме суб'єкти підприємницької діяльності впливають на економічне життя всіх наявних учасників ринку в контексті задоволення економічних інтересів. Сучасні процеси порушення ринкової рівноваги суб'єктів господарювання та іiі нерівномірного відновлення надають динамічній системі економічних інтересів нової якості. Характерною ії рисою є нерівномірний розвиток самої системи економічних відносин між суб'єктами господарювання, що вимагає регулювання всіх змін таким чином, щоб чітко проглядався позитивний ефект (економічний, соціальний, екологічний, політичний та ін.) для всіх учасників відносин.

Методи інституціональної політичної економії стали методологічною основою дослідження зазначеної проблеми, оскільки сформовані ринкові відносини в Україні характеризуються нестійкістю саме інституційнального середовища та недосконалістю механізмів правового забезпечення економічних відносин на агропродовольчому ринку.

Використання в аналізі господарської діяльності системного підходу та принципів історизму збагатило інструментарій вивчення економічного життя, зокрема проблем узгодження економічних інтересів, i дало змогу поглянути на 


\section{Agricultural and Resource Economics}

www.are-journal.com

економічний процес у динаміці й помітити особливості та риси, які не можна побачити в статичному стані. Провідну категорію інституціональної економічної теорії - «інституція» (інститут), як узагальнювальну норму, що $\epsilon$ значущою для певного часу, було запозичено з наукових досліджень німецьких учених [20]. Основоположники інституціоналізму неодноразово зверталися до проблем моралі, культури, духу суспільства тощо. Саме здобутки німецьких науковців позитивно вплинули на дальший розвиток економічної науки, зокрема іiі інституціонального напряму, збагатили теоретико-методологічну й термінологічну скарбницю вивчення економічного життя, особливо щодо інтересів його суб'єктів.

Серед українських учених А. Гриценко, В. Мамчур, М. Малік, О. Шпикуляк $[5 ; 14 ; 24] \epsilon$ прихильниками інституціональної політичної економії, яка, за висловленням А. Гриценка, дозволяє адекватно осмислити специфічні тенденції та нестандартні ситуації в умовах економіки України. Перш за все, це стосується трансформацій, які відбуваються на вітчизняному агропродовольчому ринку, а саме: розвиток неформальних економічних відносин; розширення механізмів ринкового тиску, не регламентованих офіційними інституційними методами управління; суттєве збільшення вартості капіталу власників засобів виробництва, що призвело до значного розшарування населення за доходами; монополізації ринків; розповсюдження цінової дискримінації; перекосів у розподілі доданої вартості; порушення міжгалузевих зв'язків агропродовольчого ланцюга тощо. Перераховані трансформації породжують асиметричність інформації, і зрештою - призводять до розбалансування економічних інтересів суб'єктів ринку, на чому також наголошує Є. Кирилюк [10].

Динамічні зміни системи економічних відносин призводять до необхідності перманентного узгоджування економічних інтересів усіх суб'єктів цієї системи. На цей процес впливають такі фактори, як особливості господарської діяльності суб'єктів, обсяг і складність вирішуваних завдань, рівень соціально-економічного розвитку суспільства (території), який залежить від здатності соціально-політичної системи забезпечувати його стабільність в умовах глобалізації.

На нашу думку, саме В. Смєсова на підставі результатів наукового аналізу розвитку системи поглядів щодо економічних інтересів і виділення основних етапів еволюції їхніх теорії й досить чітко охарактеризувала сучасний етап розвитку теорії економічних інтересів. Етапом синергії (з 70-х рр. ХХ ст. до сьогодні) авторка називає сучасний період [19].

Характерними ознаками етапу синергії авторка вважає, по-перше, складність і системність (представлення економічних інтересів як складної системи взаємодії гетерогенних характеристик, чинників й аспектів, які визначають економічні прагнення суб'єктів ринку). Наявністю різних за своїм змістом і походженням економічних інтересів, форм їх реалізації, чинних норм, інститутів, механізмів їх координації та узгодження зумовлено виникнення 


\section{Agricultural and Resource Economics}

www.are-journal.com

різноманітних теоретичних концепцій, якими висвітлюються певні ракурси формування та реалізації економічних інтересів суб'єктів економічних відносин.

По-друге, характерним є емерджентність системи економічних інтересів (наявність у системи властивостей, які не притаманні іï елементам, або неможливість зведення властивостей системи до суми властивостей iіi компонентів).

По-третє, в концепціях XX ст. економічні інтереси характеризуються динамічністю (постійною мінливістю, перманентним розвитком, удосконаленням у часі й просторі). Динамічність і нерівномірність розвитку викликає загострення конфліктів інтересів економічних суб'єктів, від яких вимагає швидкої реакції на зазначені зміни, і відповідно, ставить перед науковцями завдання щодо розробки механізмів стимулювання відтворення економічних інтересів.

Разом 3 тим на етапі синергії економічним інтересам притаманні такі явища як нестійкість, випадковість і нелінійність. Зазначене призводить до коливань і непрогнозованих змін економічних прагнень. I тоді незначні зміни параметрів, або поведінки суб'єкта динамічної системи призводять до суттєвих змін усієї системи економічних інтересів, тобто мікропараметри продукують глибинні та глобальні трансформації стану всієї соціально-економічної системи, повну зміну траєкторії руху, появу абсолютно нових варіантів дальшого розвитку [19, с. 75-76].

Аналізуючи сучасний економічний стан постсоціалістичних країн, Т. Сьомкіна виокремлює три інституціональні типи економічних суб'єктів, що виконують підприємницькі функції:

а) приватні підприємці, які $є$ провідниками економічних інтересів у малому та середньому бізнесі;

б) директори державних підприємств і керівники акціонерних товариств, у яких державі належить контрольний пакет акцій, що формують свої інтереси під впливом як ринкових чинників, так і державницьких позицій;

в) представники місцевої влади та інших бюрократичних структур, інтереси яких мають досить чітко визначений рівневий, груповий характер [21].

На думку Т. Сьомкіної, найбільшою проблемою сучасного етапу розвитку суб'єктів підприємницької діяльності є несформованість реальних ефективних функціональних форм економічних суб'єктів та економічного простору, що повинно призводити до їх розвитку. Як наслідок, маємо такі соціальноекономічні умови, в яких саме існування суб'єктів підприємницької діяльності здійснюється в неадекватних інституціональних формах [21].

Кінцевою метою узгодження економічних інтересів $\epsilon$ подолання їх суперечливості (протиріч), шляхом пошуку різних способів їх співіснування. Мова йде про співіснування інтересів бізнесу та найманих працівників, населення та бізнесу, бізнесу й держави, держави та населення, які дуже суперечливі, особливо щодо розподілу доходів, зокрема доданої вартості. 


\section{Agricultural and Resource Economics \\ www.are-journal.com}

Під співіснуванням ми розуміємо одночасне спільне існування врахованих та узгоджених економічних інтересів кожного учасника відносин. Тільки шляхом надавання їм імпульсу одновекторного розвитку та визначення проміжних цілей можна досягти повсюдного стійкого інклюзивного, в тому числі соціально-економічного, розвитку країни. Головною умовою $є$ те, що інтереси більшості суб'єктів господарювання мають бути спрямовані на реалізацію саме визначеної мети. На наше переконання, такою метою повинно стати формування вертикальних, формальних, довгострокових, регулярних (стійких), взаємовигідних і надійних міжгалузевих відносин, які зумовлені технологічними особливостями виробництва продукції тваринництва.

Узгоджений та злагоджений розвиток економічних відносин на ринку продукції тваринництва забезпечує синхронність і ритмічність у роботі всіх учасників передбачених організаційно-технологічних процесів створення сільськогосподарської продукції - від виробника до кінцевого споживача (рис. 1).

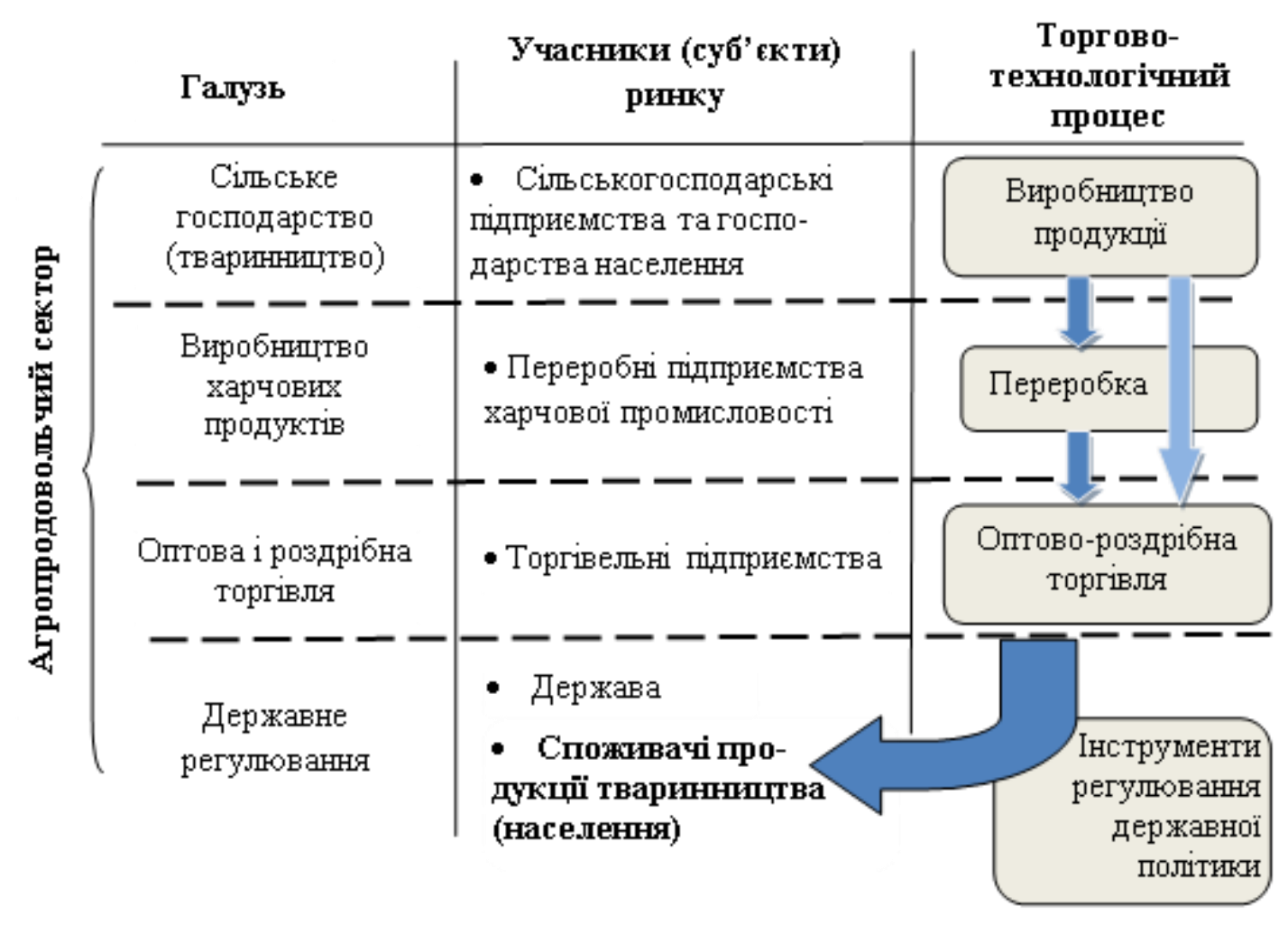

\section{Рис. 1. Блок-схема агропродовольчого ланцюга поставок тваринницької

$$
\text { продукції }
$$

Джерело: розроблено автором.

Одним із важливих завдань щодо формування перерахованих економічних відносин сільськогосподарських виробників на агропродовольчому ринку $\epsilon$ забезпечення якомога повнішого врахування інтересів більшості учасників цього ринку. Але врахування інтересів не $\epsilon$ самоціллю. Скоріше це необхідність, оскільки $є$ першочерговим у контексті гарантування продовольчої безпеки. 


\section{Agricultural and Resource Economics \\ www.are-journal.com}

Згідно 3 дослідженнями вчених ННЦ «Інститут аграрної економіки», національна структура споживчої (роздрібної) ціни на молоко має такий вигляд: частка виробників - до $25 \%$; частка суб'єктів переробки - до 53 \%; частка представників торгівлі - понад $20 \%$. У розвинутих країнах це співвідношення має зовсім іншу структуру: сировина $-50 \%$, переробка $-25 \%$, торгівля - $25 \%$ [2].

Наші дослідження також підтверджують низький відсоток участі вітчизняних виробників продукції тваринництва в структурі споживчої (роздрібної) ціни, за винятком продукції птахівництва (рис. 2).

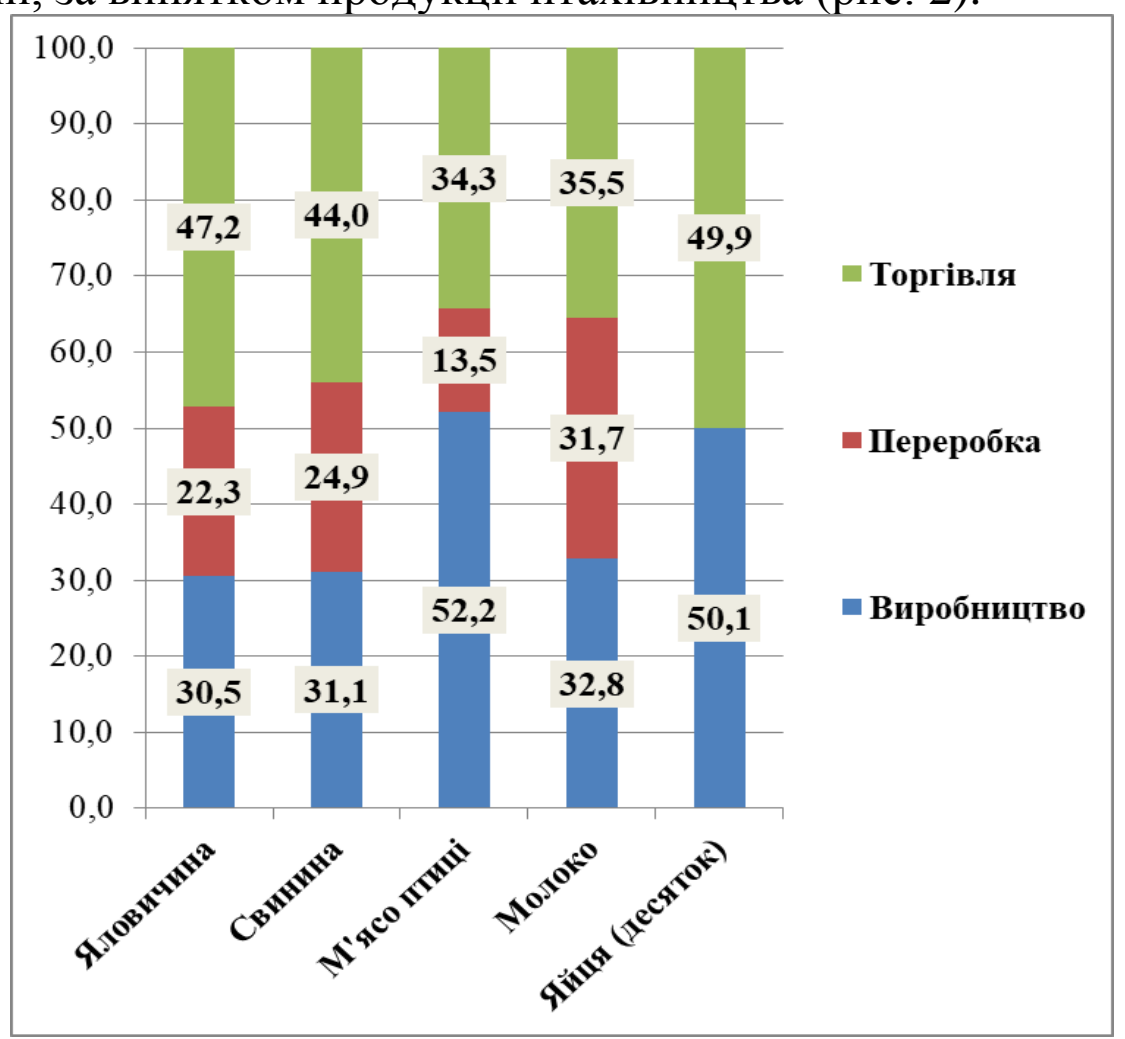

\section{Рис. 2. Структура споживчих цін продукції тваринництва}

\section{(січень 2019 року), \%}

Джерело: розраховано автором за даними Державної служби статистики України.

Отже, частка українського сільськогосподарського виробника в структурі роздрібної ціни не задовольняє його економічних інтересів як суб'єкта господарювання, метою якого, звісно, є здійснення розширеного відтворення виробництва. Підтвердженням $\epsilon$ значне скорочення виробництва м'ясомолочної продукції.

У своїх дослідженнях О. О. Красноруцький підсумовує, що домінування економічних інтересів саме торговельних посередників, непропорційність концентрації та ефективності функціонування капіталу, розміщеного у сферах виробництва та обігу, наближення конкурентної ситуації на ринках збуту сільськогосподарської продукції до стану олігопсонії є причинами фактичного унеможливлення суттєвого впливу щодо заходів 3 підвищення конкурентоспроможності сільгоспвиробників, крім спрямованих на зрушення в механізмах ціноутворення [13, с. 38]. 
Як зазначає Є. М. Кирилюк [10], процес формування складної системи відносин на ринку поступово перетворився з безпосередньої умови реалізації інтересів (шляхом досягнення визначених цілей) на механізм їх консервації. Вже понад 10 років незмінною залишається частка сільгоспвиробників продукції тваринництва у споживчій ціні кінцевої продукції. Консервативні економічні інтереси стали реалізовуватися не завдяки діям, підпорядкованим конкурентній логіці щодо, наприклад, підвищення продуктивності праці, методів організації торгівлі, цінової політики, додаткової переробки продукції тощо, а шляхом використання механізмів впливу - ринкової сили, яка сформувалася системою наявних неформальних відносин. Про це також наголошують і А. Гриценко [5], і Л. Глубіш [4].

Для пізнання та ідентифікації інтересів учасників аграрного ринку при аналізі ринкових трансакцій Є. М. Кирилюк пропонує враховувати такі показники:

1) питома вага контрагента (посередницької організації, переробного підприємства та ін.) в діяльності сільськогосподарського виробника або маркетингового кооперативу, що демонструє «масштаб присутності» певної комерційної структури у діяльності товаровиробника та є абсолютним або відносним вираженням обсягу двосторонніх операцій із цим контрагентом протягом певного періоду;

2) активність або регулярність здійснення операцій певного виду між учасниками (може виражатись у процентах до загальної кількості операцій за досліджуваний період);

3) коефіцієнт доходності (відображає співвідношення доходу на одиницю продукції, отриманого від іiі реалізації певному контрагенту, та відповідного середнього доходу за певний період або ж від операцій 3 іншими контрагентами) [10, с. 68].

На жаль, використати запропоновані Є. М. Кирилюком показники на практиці, під час пізнання та ідентифікації інтересів учасників агропродовольчого ринку, $є$ складним завданням. Більшість даних для розрахунків $є$ комерційною інформацією, яка не підлягає розголошенню (наприклад, умови контракту (угоди) щодо обсягів і ціни продажу). Також не $є$ зрозумілим, як співвідношення доходу на одиницю продукції та середнього доходу ідентифікує інтерес того чи іншого суб'єкта? Адже особливістю сільськогосподарської продукції є іï неоднорідність за якістю; наприклад, молоко кожного дня може бути різної якості за вмістом жиру та білка, відповідно, виходячи з логіки автора, кожного дня має змінюватися й інтерес?

Учені В. Рябоконь разом 3 Н. Новіковою пропонують використовувати «якісну економічну оцінку» економічних інтересів суб'єктів аграрної сфери задля забезпечення прийняття економічно обгрунтованих, справедливих управлінських рішень у системі державного регулювання. На думку авторів, модельна схема методичного підходу дає можливість встановлювати взаємозв'язок між основними показниками ефективності господарювання 


\section{Agricultural and Resource Economics}

www.are-journal.com

підприємств у контексті їх впливу на рівень досягнення цілей на ринку. Концептуальна схема оцінок (дослідження) економічних інтересів суб'єктів господарювання передбачає застосування «блокового» підходу. Автори виділяють блоки економічних інтересів та ефекти (показники або об'єкти оцінювання), а саме: економічний блок (прибуток, рівень рентабельності, собівартість продукції, валова продукція, продуктивність праці); соціальний блок (динаміка розбудови соціальної сфери та побутових умов життя й праці на селі); ринково-інфраструктурний блок (інфраструктурні проекти 3 обслуговування аграрного виробництва й процесу взаємодії учасників ринку в системі «виробництво-обмін-розподіл-споживання») та інституційно-правовий блок (інституційні умови агрогосподарювання та система їх нормативноправового забезпечення на всіх рівнях [18, с. 18]. Запропонований блоковий підхід, на наш погляд, не дає відповіді на запитання щодо рівня узгодженості (задоволеності) інтересів учасників економічних відносин, особливо сільськогосподарських виробників.

Учений Є. М. Кирилюк пропонує включити до апарату економічних досліджень терміни «ресурс впливу» і «капітал впливу». «Ресурс впливу», згідно 3 автором, $є$ інтегрованим показником, який характеризує здатність ринкового суб'єкта реалізовувати свої економічні інтереси та здобувати конкурентні переваги завдяки налагодженню певної системи взаємозв’язків. Для характеристики такого ресурсу автор пропонує такі категорії: цінність, рідкісність, невідтворюваність і незамінність.

«Капітал впливу» - це конкретна вартісна форма ресурсу впливу, цінність системи відносин, яка залежить від поточного стану інституційного середовища та механізмів позиціювання суб'єкта в ньому. Збільшити капітал впливу можна лише одним способом - шляхом поступового нагромадження відповідного власного капіталу впливу, що набувається виключно в результаті тривалої адміністративної та маркетингової роботи, 3 одночасним налагодженням відносин, зокрема неформальних, з окремими представниками органів влади» $[10$, с. 68]. Отже, автор припускає, що налагодження неформальних відносини 3 представниками органів влади є запорукою нарощування «капіталу впливу», який має «вартісну форму». Водночас Є. М. Кирилюк зазначає, що «...3 точки зору реалізації інтересів, немає нічого гіршого, ніж зміна «правил гри» під час самої гри» [10, с. 69]. На нашу думку, існування певних подвійних стандартів суттєво деформує рівень узгодженості інтересів між усіма учасниками економічних відносин, що призводить до непрогнозованості й некерованості загального розвитку економічної системи. Негативні наслідки від таких процесів відчувають, зокрема, й ініціатори «подвійних стандартів».

Згідно 3 висновками Л. Осіпової, реалізація економічних інтересів здійснюється через досягнення їхніми суб'єктами конкретних економічних цілей. Під економічним інтересом авторка розуміє «реальний, зумовлений відносинами власності та принципом економічної вигоди мотив і стимул соціальних дій щодо задоволення динамічних систем індивідуальних потреб» 


\section{Agricultural and Resource Economics}

www.are-journal.com

$[16$, c. 255], додаючи, що значною мірою інтереси виступають як соціальні протилежності. У сфері виробництва підприємці та робітники є протилежними сторонами економічних стосунків, проте, вони мають спільні інтереси щодо ринку, виступаючи як виробники або споживачі. Не задовольнивши інтереси споживача, виробник не може забезпечити і власні інтереси. Взаємозалежність цих груп об'єктивно зумовлює їх співробітництво. Отже, на думку Л. Осіпової, механізм узгодження інтересів визначається, насамперед, сутністю існуючої економічної системи. Державна політика у сфері економічних інтересів грунтується на тому, що за різних умов суспільного розвитку на перший план можуть виходити ті чи інші інтереси. Якщо вчасно не зробити в економічній політиці акцент на певну групу інтересів, то результатом буде відсутність узгодженості інтересів, що гальмує загальний соціально-економічний розвиток. Безсумнівно, важливо досягти якомога повнішої внутрішньої узгодженості інтересів [16].

Ми вже розглянули особливості сучасного етапу розвитку теорії економічних інтересів, навели приклад прийомів ідентифікації інтересів учасників аграрного ринку, наступним етапом $\epsilon$ проведене дослідження існуючих форм узгодження економічних інтересів суб'єктів господарювання та інструментів визначення рівня узгодженості інтересів.

Є різноманітні форми гармонізації інтересів суб'єктів ринку. Це такі традиційні ринкові, як акціонування, кооперація, страхування, конкуренція, банкрутство та форми, пов'язані з посиленням соціальної відповідальності особистості й держави: голосування, бюджетування, лобіювання, партнерство тощо.

Основною формою узгодження економічних інтересів господарюючих суб'єктів агропродовольчого сектора економіки $\epsilon$ інтеграція. Великим інтегрованим структурам набагато простіше відстоювати власні інтереси під час взаємодії $з$ державними та ринковими структурами. Суб'єктом лобіювання на державному рівні не може бути окремий дрібний чи середній підприємець. Лобіювання є, перш за все, сферою діяльності груп тиску спілок та об'єднань підприємців, а також великих господарських структур. Світовий досвід свідчить, що прогресивні сільськогосподарські компанії в розвинених країнах здебільшого прагнуть до консолідації економічної діяльності.

Інтегровані структури не $є$ новими для української економіки формами задоволення інтересів суб'єктів господарювання для досягнення ними загальних стратегічних цілей, зміцнення та розширення ринків, поділу ризиків $\mathrm{i}$ прибутків. Такі економічні структури відкривають унікальні можливості для об'єднання з широким колом партнерів, включаючи клієнтів, постачальників, конкурентів, представників держави, дозволяючи долати протиріччя між суб'єктами господарювання 3 різним стилем ведення бізнесу. Створення економічно інтегрованих структур зменшує бар'єри та спрощує доступ до зовнішніх ринків, підвищує рівень конкуренції і $є$ вигідним для всіх партнерів економічного об'єднання. 


\section{Agricultural and Resource Economics}

www.are-journal.com

Досліджуючи теоретичні платформи груп економічних інтересів, Л. Глубіш дійшла висновку, що взаємозалежність груп інтересів зумовлює їх співробітництво, бо не задовольнивши економічні інтереси один одного, жодна 3 груп не може реалізувати власні [4]. Тому визначення економічних інтересів, їх групування, аналіз, реалізацію через узгодження автор вважає сполучною ланкою між різними складовими частинами економічної системи країни.

У ході економічних відносин між виробниками та споживачами, між державним і недержавним секторами економіки мають місце елементи боротьби та співробітництва, через це, крім узгодженої ринкової взаємодії, можливою ії̈ формою Л. Глубіш називає конфлікт груп економічних інтересів. Такі протиріччя ринок не може вирішити самостійно. Тому в узгодженні економічних інтересів важливу роль відіграє саме державна політика. Державні економічні інтереси повинні врівноважувати ступінь задоволення економічних інтересів виробників і споживачів в умовах ринкової економіки. Сам механізм узгодженої взаємодії груп економічних інтересів нагадує годинниковий, для злагодженої роботи якого всі його елементи повинні рухатись у напрямі досягнення власних цілей, гарантуючи, тим самим, свій внесок у розвиток

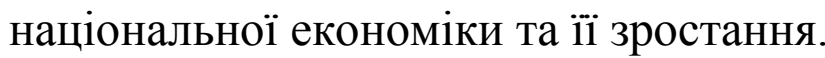

Але треба враховувати, що будь-який механізм приводить у дію людина, як носій особистих інтересів, які не завжди співпадають з інтересами розвитку суспільства, тому слід розрізняти індивідуальний та суспільний інтереси. Отже, для ринкової форми організації суспільного виробництва та реалізації економічних інтересів характерним $є$ зростання їх суперечливості, протилежності та контрасту [23].

На думку Л. Глубіш, економіка, як система, не може допустити виникнення конфлікту між групами економічних інтересів, оскільки це спричиняє виникнення криз, що призводить до фінансових втрат [4, с. 21]. Але, будь-яка криза - це час нових можливостей. I тільки на основі існуючих криз, стресів та дисгармонії закладається потужний «імунітет» подолання протиріч інтересів у подальшому. Іншими словами, формуються механізми єдності (співіснування) різноманітних інтересів учасників злагодженої системи економічних відносин [11].

Гармонізацією економічних інтересів учасників ринку сільськогосподарської продукції, наголошує О. Красноруцький, забезпечується усунення умов для виникнення цінового диктату 3 боку тієї чи іншої функціональної групи підприємств-учасників ринку [13, с. 43-44].

Отже, саме рівноважна ціна $є$ індикатором тимчасового узгодження протилежних, суперечливих економічних інтересів учасників ринку. Вільний ринок виступає механізмом координації, узгодження інтересів усіх суб'єктів взаємодії через систему цін. Саме держава створює умови для формування рівноважної системи цін.

Ми повністю погоджуємся із думкою В. Смєсової, що економічні інтереси і подальша поведінка економічних суб'єктів залежать від багатовимірної 


\section{Agricultural and Resource Economics}

www.are-journal.com

сукупності їх внутрішніх уподобань, уявлень, прагнень, які виникають у певний проміжок часу, у певних економічних умовах. Та одночасно інтереси суб'єктів залежать від впливу зовнішніх регуляторів і суспільного й інституційного тиску на «больові» точки. Співіснування, когерентність і взаємовплив внутрішніх цінностей людини та зовнішнього світу складають оболонку іiі економічних інтересів і визначають напрями дальшої економічної діяльності [19, с. 76].

У науковій літературі важко знайти інформацію щодо простих i оперативних інструментів вимірювання рівня узгодженості (задоволеності) економічних інтересів суб'єктів ринку, особливо такого складного (в організаційному розумінні) та соціально значущого (у розумінні продовольчої безпеки) ринку, як агропродовольчий. Науковці пропонують використовувати доволі громіздкі й складні методи економетрії на основі розрахунку лінійних коефіцієнтів кореляції, індексів кореляції, які, начебто, дозволяють оцінювати як однорідні, так і різнорідні економічні інтереси 3 огляду на встановлення тісноти зв'язку між ними. Але автори не враховують, що безліч різнорівневих, суперечливих економічних завдань, пов'язаних з вирівнюванням економічних умов господарювання суб'єктів ринку, 3 питаннями Згладжування диспропорцій їх розвитку.

На нашу думку, саме отриманий рівень доданої вартості $є$ одним із таких показників і результативності, й ефективності господарювання усіх учасників ринкових відносин. Створення доданої вартості $є$ процесом додавання вартості на шляху виробництва та реалізації продукції з метою іiі «економічного» розподілу.

Згідно 3 Національним класифікатором України видів економічної діяльності додана вартість, як базис оподаткування, відображає різницю між випуском продукції за основною ціною та проміжним споживанням за цінами покупців. Проміжне споживання - це витрати на товари та послуги (сировину, паливо, енергію, поточний ремонт, послуги транспорту тощо), що їх використовують суб'єкти господарювання для виробничих потреб.

Таким чином, у розмір доданої вартості входять: величина доходу працівника (у вигляді витрат на персонал), величина «номінального» прибутку (збитку), який декларує роботодавець-суб'єкт господарювання, розмір його «реального» доходу на вкладений капітал і величина доходу держави (у вигляді податків). Тому вважаємо, що розмір і структура елементів доданої вартості таких, як витрати на персонал і величина отриманого прибутку (збитку), можуть бути інструментами кількісного визначення рівня узгодженості інтересів усіх учасників економічних відносин.

Отже, з метою визначення рівня узгодженості інтересів основних суб'єктів господарювання ринку продукції тваринництва і для більшої об'єктивності й порівнянності результатів, ми розрахували розмір доданої вартості, отриманої кожним учасником (за галузями та видами економічної діяльності) 3 розрахунку на одного зайнятого. Кількість зайнятих працівників за видами економічної діяльності в Україні та ії динаміку наведено на рис. 3. 


\section{Agricultural and Resource Economics \\ www.are-journal.com}

Ми вибрали такі групи підприємств, які прямо належать до учасників економічних відносин на ринку продукції тваринництва, згідно 3 Класифікацією видів економічної діяльності (КВЕД-2010): тваринництво (01.4); виробництво м'яса та м'ясних продуктів (10.1); виробництво молочних продуктів (10.5); оптова торгівля сільськогосподарською сировиною та живими тваринами (46.2); оптова торгівля продуктами харчування, напоями та тютюновими виробами (46.3); роздрібна торгівля продуктами харчування, напоями та тютюновими виробами в спеціалізованих магазинах (47.2).

Було побудовано діаграму (знизу-вверх), саме так, як здійснюється вертикальний організаційно-технологічний рух продукції тваринництва від сільськогосподарського виробника до кінцевого споживача.

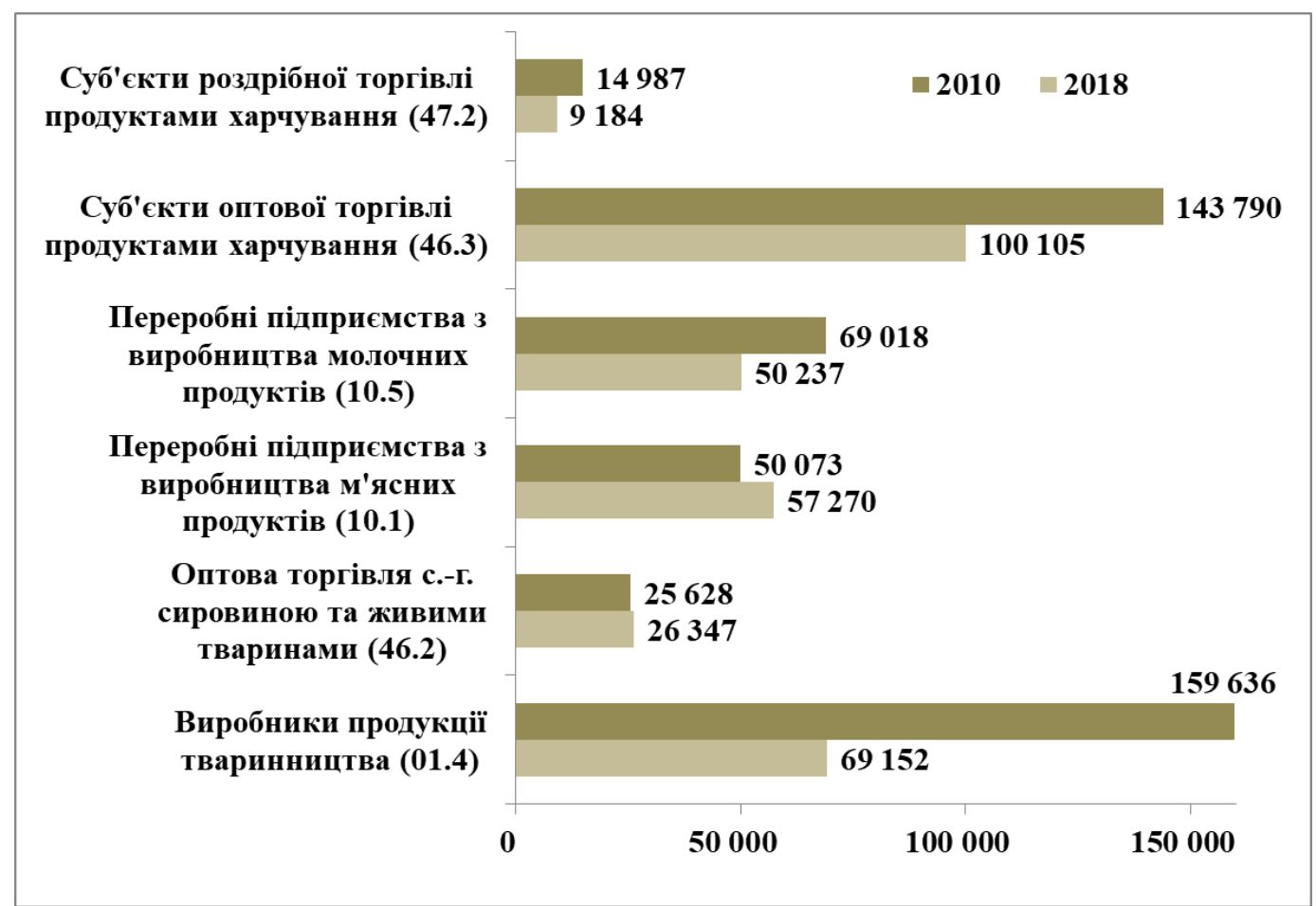

\section{Рис. 3. Динаміка кількості зайнятих працівників за видами економічної діяльності в Україні (2010 і 2018 роки), осіб}

Джерело: сформовано автором за даними Державної служби статистики України.

Отримані дані свідчать про неоднозначні зміни в кількості зайнятих осіб за видами економічної діяльності представників ринку продукції тваринництва за останні майже 10 років. Так, спостерігається суттєве скорочення кількості зайнятих працівників у безпосередніх виробників продукції, які утримують $\mathrm{i}$ вирощують тварин, а саме у 2,3 раза (з майже 160 тис. осіб до лише 69,1 тис. осіб); зменшується кількість зайнятих у переробних підприємствах 3 виробництва молочної продукції на 27,3 \% до 50,2 тис. осіб і суб'єктів роздрібної торгівлі в 1,6 раза до 9,2 тис. осіб; також відносно виробників (зменшення у 2,3 раза) незначне зменшення представників оптової торгівлі продуктами харчування - на $30 \%$, тобто до 100 тис. осіб.

Водночас спостерігається збільшення кількості представників оптової торгівлі сільськогосподарською сировиною та живими тваринами на 3 \% до 


\section{Agricultural and Resource Economics \\ www.are-journal.com}

26,3 тис. осіб і переробних підприємств 3 виробництва м'ясної продукції на $14,4 \%$ до 57,3 тис. осіб. Також можна помітити, що на одного зайнятого в сільськогосподарському виробництві припадає майже два представника оптової торгівлі та 1,5 особи з переробки продукції.

Отже, ми поступово підійшли до визначення отриманої доданої вартості, витрат на персонал та отримання чистого прибутку (збитку) на кожного зайнятого на ринку продукції тваринництва (рис. 4).

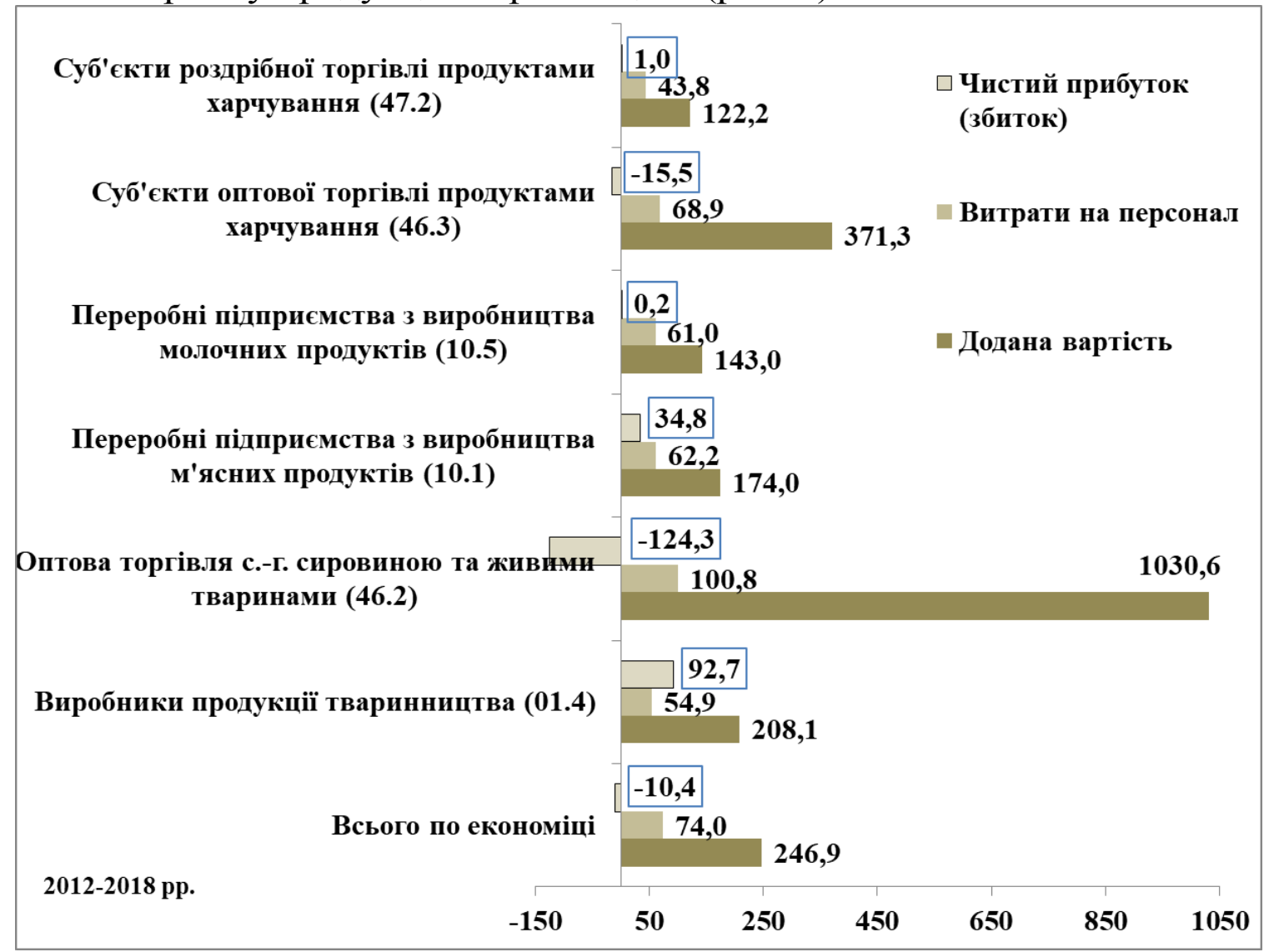

Рис. 4. Розрахунок прибутку (збитку), витрат на персонал і доданої вартості на одного зайнятого за видами економічної діяльності в Україні (у середньому за 2012-2018 рр.), тис. грн

Джерело: розраховано автором за даними Державної служби статистики України.

Результати розрахунку виявилися неочікуваними. При цьому ми помітили певні закономірності. Так, розмір отриманої доданої вартості коливається від 122,2 тис. грн на одного зайнятого працівника в роздрібній торгівлі до трохи більше 1 млн грн - в оптовій торгівлі сільськогосподарською сировиною; середній рівень по країні становить 247 тис. грн. Суттєво коливається розмір здобутого прибутку (збитку), а саме: від збитковості у 124 тис. грн на особу в представників оптової торгівлі до 93 тис. грн прибутку на кожного зайнятого працівника у виробників продукції тваринництва. Витрати на персонал також відрізняються за видами економічної діяльності від 44 тис. грн на особу в роздрібній торгівлі до 100 тис. грн - у представників оптової торгівлі сільськогосподарською сировиною.

Якщо порівнювати дані із середнім рівнем в Україні (табл. 1), то різниця в 


\section{Agricultural and Resource Economics}

www.are-journal.com

розмірі отриманої доданої вартості коливається від 49,5\% рівня країни представників роздрібної торгівлі, до 150 і майже 420 \% представників оптової торгівлі. Витрати на персонал коливаються від 59 до $136 \%$ представників, відповідно, роздрібної та оптової торгівлі.

Таблиия 1

Порівняльний аналіз отриманої доданої вартості з розрахунку на одного зайнятого (за видами економічної діяльності)

\begin{tabular}{|c|c|c|c|c|c|c|c|}
\hline Показник & $\begin{array}{l}\text { Усього в } \\
\text { економіці }\end{array}$ & 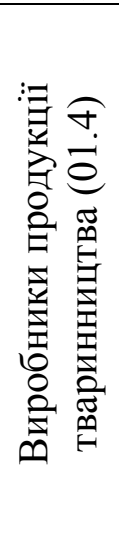 & 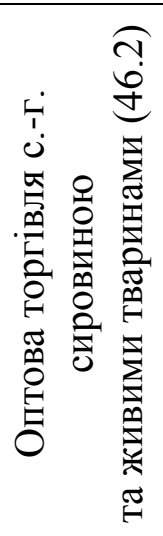 & 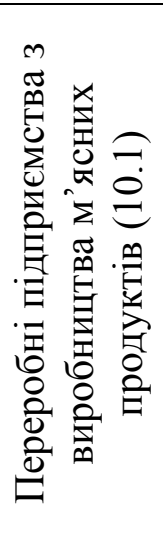 & 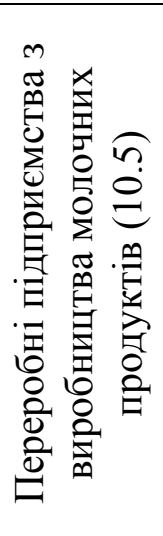 & 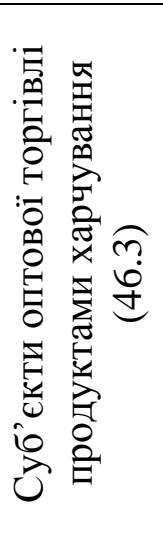 & 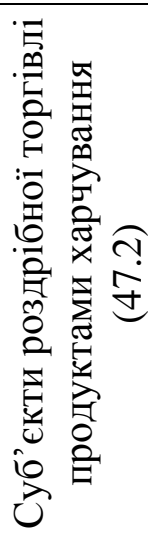 \\
\hline \multicolumn{8}{|c|}{ У середньому за 2012-2018 рр., тис. грн } \\
\hline $\begin{array}{l}\text { Додана } \\
\text { вартість }\end{array}$ & 246,9 & 208,1 & 1030,6 & 174,0 & 143,0 & 371,3 & 122,2 \\
\hline $\begin{array}{l}\text { Витрати на } \\
\text { персонал }\end{array}$ & 74,0 & 54,9 & 100,8 & 62,2 & 61,0 & 68,9 & 43,8 \\
\hline $\begin{array}{l}\text { Чистий } \\
\text { прибуток } \\
\text { (збиток) }\end{array}$ & $-10,4$ & 92,7 & $-124,3$ & 34,8 & 0,2 & $-15,5$ & 1,0 \\
\hline \multicolumn{8}{|c|}{ Відносно рівня в Україні за 2012-2018 рр., \% } \\
\hline $\begin{array}{l}\text { Додана } \\
\text { вартість }\end{array}$ & 100 & 84,3 & 417,5 & 70,5 & 57,9 & 150,4 & 49,5 \\
\hline $\begin{array}{l}\text { Витрати на } \\
\text { персонал }\end{array}$ & 100 & 74,2 & 136,3 & 84,1 & 82,5 & 93,2 & 59,2 \\
\hline
\end{tabular}

Джерело: розраховано автором за даними Державної служби статистики України.

Отже, в тих галузях, на які припадає найбільший рівень доданої вартості, спостерігається така суперечлива комбінація явищ, як збільшення кількості зайнятих працівників за максимальної збитковості бізнесу. Для об'єктивного аналізу необхідно дослідити, по-перше, що дозволяє представникам оптової торгівлі мати такий великий розмір доданої вартості (у 4,2 раза більший від рівня країни); по-друге, знайти відповідь на питання: чому і як за надвисокого рівня доданої вартості, зазначеним учасникам ринку продукції тваринництва вдається працювати найзбитковіше порівняно з усіма іншими учасниками? Але для цього потрібне окреме наукове дослідження. Тому наступні наші пошуки будуть спрямовані на виявлення причин таких суттєвих перекосів у результативності й ефективності діяльності пов'язаних суб'єктів господарювання та механізмів гармонізації економічних відносин між учасниками ринку в умовах існуючого складного економічного простору.

Висновки. У ході дослідження характерних ознак, факторів $\mathrm{i}$ форм 


\section{Agricultural and Resource Economics}

www.are-journal.com

реалізації економічних інтересів учасників ринку продукції тваринництва та пошуку інструментарію вимірювання рівня узгодженості їх інтересів, з’ясовано таке:

- характерною рисою сучасних економічних інтересів суб'єктів ринку продукції тваринництва $є$ їх розбалансованість унаслідок таких трансформацій: розвиток неформальних економічних відносин; розширення інструментів ринкового тиску, не регламентованих офіційними інституційними нормами; суттєве розшарування населення за доходами; розвиток монополізації ринків; розповсюдження цінової дискримінації; перекоси в розподілі доданої вартості. Усе це суттєво ускладнило міжгалузеві зв'язки агропродовольчого ринку. Разом із тим, економічним інтересам притаманні такі явища, як нестійкість, випадковість та нелінійність;

- головною умовою стійкого інклюзивного розвитку країни, зокрема соціально-економічного, є те, що інтереси більшості суб'єктів господарювання мають бути спрямовані на реалізацію єдиної визначеної мети - формування вертикальних, формальних, довгострокових, регулярних (стійких), взаємовигідних і надійних міжгалузевих відносин, які зумовлені технологічною особливістю виробництва продукції тваринництва;

- узгоджений (злагоджений) розвиток економічних відносин на ринку продукції тваринництва забезпечується синхронністю та ритмічністю в роботі всіх учасників під час проходження сільськогосподарською продукцією передбачених організаційно-технологічних процесів (від виробника до кінцевого споживача). Тому основною формою узгодження економічних інтересів при цьому має стати інтеграція шляхом кооперації сільськогосподарських виробників на всіх рівнях (міжгосподарському, міжгалузевому, з кінцевим споживачем тощо).

- державні національні економічні інтереси повинні врівноважувати ступінь задоволення економічних інтересів як виробників продукції (незалежно від виду економічної діяльності), так і споживачів щодо кількості, якості й асортименту продукції тваринництва в контексті продовольчої безпеки.

У ході пошуку шляхів розширення інструментарію для визначення рівня узгодженості (задоволеності) економічних інтересів учасників ринку продукції тваринництва доведено, що розрахунок величини доданої вартості, отриманої на кожного зайнятого працівника (за видами економічної діяльності), може слугувати прийомом кількісного вираження рівня узгодженості економічних інтересів суб'єктів будь-якого ринку, об'єднаних організаційно-технологічним процесом. Перспективні пошуки будуть спрямовані на виявлення причин суттєвих перекосів у результативності й ефективності діяльності пов'язаних суб’єктів господарювання та механізмів гармонізації економічних відносин між учасниками ринку в умовах існуючого складного економічного простору.

\section{Список використаних джерел}

1. Антощенкова В. В., Кравченко О. М. Економічна ефективність виробництва та реалізації молока в Україні. Актуальні проблеми інноваційної 
економіки. 2016. № 3. С. 39-44.

2. Боднар О. В., Козак О. А., Копитець Н. Г. Напрями врегулювання взаємовідносин виробників, продавців і споживачів соціально-значимих продуктів харчування. Економіка АПК. 2014. № 2. С. 42-50.

3. Геєць В. М. Економіка України: ключові проблеми і перспективи. Економіка і прогнозування. 2016. № 1. С. 7-22.

4. Глубіш Л. Я., Теоретичні платформи груп економічних інтересів та їх узгодження в ході ринкової взаємодії. Економіка та держава. 2015. № 12. C. $17-23$.

5. Гриценко A. Институциональная политическая экономия: методологический потенциал и новые возможности. Формування ринкової економіки. 2011. Спец. випуск: Методологічні проблеми сучасної політичної економії. С. 21-31.

6. Грищенко А. Інтеграційний вектор реалізації національних економічних інтересів України: теоретичні та практичні аспекти. Міжнародна економічна політика. 2011. Вип. 1-2. С. 246-274.

7. Далевська Н. М.Національні економічні інтереси України в умовах глобальної конкуренції. Економічний часопис-XXI. 2012. № 11-12. С. 15-18.

8. Дем'яненко С. І. До питання про стратегію розвитку аграрного сектору економіки України. Економіка АПК. 2014. № 1. С. 14-19.

9. Зінчук Т. О. Свропейська інтеграція: проблеми адаптації аграрного сектора економіки України: монографія. Житомир: ДВНЗ «Держ. агроекол. унT», 2008. $384 \mathrm{c}$.

10. Кирилюк Є. М. Реалізація інтересів суб'єктів аграрного ринку у господарській системі сучасної України. Економіка України. 2012. № 11. С. 6275 .

11. Кравченко О. М. Гармонізація економічної системи. Економіка АПК. 2017. № 11. С. 51-56.

12. Кравчук I. Організаційне забезпечення створення доданої вартості агропродовольчої продукції. Agricultural and Resource Economics. 2018. Vol. 4. No. 3. Pp. 71-85. URL: http://www.are-journal.com.

13. Красноруцький О. О., Зайцев Ю. О. Адаптивні механізми в системах управління конкурентоспроможністю продукції аграрних підприємств. Галииький економічний вісник. 2016. Т. 50. № 1. С. 37-46.

14. Малік М. Й., Шпикуляк О. Г., Мамчур В. А. Інституційна формалізація розвитку сімейних фермерських господарств в Україні. Економіка АПК. 2018. № 10. C. 72-85. https://doi.org/10.32317/2221-1055.201810072.

15. Новікова Н. Л. Напрями державного регулювання та оцінка економічних інтересів в аграрній сфері. Інвестииії: практика та досвід. 2015. № 15. C. 42-44.

16. Осіпова Л. В.Проблеми класифікації та взаємодії інтересів. Вісник Хмельницького наиіонального університету. 2014. № 1. С. 247-256.

17. Пасхавер Б. Й. Продовольче самозабезпечення населення України. 


\section{Agricultural and Resource Economics}

www.are-journal.com

Економіка АПК. 2018. № 1. С. 5-10.

18. Рябоконь В. П., Новікова Н. Л. Удосконалення державного регулювання економічних інтересів аграрної сфери. Економіка АПК. 2016. № 3. C. 14-20.

19. Смєсова В. Л. Основні етапи розвитку теорії економічних інтересів. Проблеми економіки та політичної економії. 2017. № 2. С. 65-85.

20. Стрішенець О., Галянт С. Інституціональна економічна теорія: науково-теоретичні передумови зародження (німецька історична школа). Економічний часопис Східноєвропейського національного університету імені Лесі Українки. 2018. Vol. 1. No. 13. P. 16-21. https://doi.org/10.29038/2411-40142018-01-16-21.

21. Сьомкіна Т. В. Теоретичні підходи до аналізу функціонування суб'єкта підприємницької діяльності. Економіка. Менеджмент. Бізнес. 2017. № 3. С. 28 34.

22. Тарасевич В. Н. К гносеологии государственного капитализма. Проблеми економіки та політичної економії. 2017. № 4. С. 59-82.

23. Чорна О. Ю., Глубокова Н. В. Узгодження економічних інтересів як підгрунтя забезпечення економічної безпеки підприємства. Менеджмент: розвиток, теорія та практика: матер. наук.-практ. конф., 15 листопада-15 грудня 2013 р. Сєверодонецьк, 2013. С. 48.

24. Шпикуляк О. Г. Інституції у розвитку та регулюванні аграрного ринку: монографія. Київ: ННЦ «ІАЕ», 2010. 396 с.

25. Шпичак О. М. Аналіз поточної кон'юнктури і прогноз ринків тваринницької продукції в Україні: монографія. Київ: ННЦ «IAE», 2017. 301 с.

26. Canning P., Weersink A., Kelly J. Farm share of the food dollar: an IO approach for the United States and Canada. Agricultural Economics. 2016. Vol. 47. Pp. 505-512. https://doi.org/10.1111/agec.12250.

27. Cucagna M. E., Goldsmith P. D. Value adding in the agri-food value chain. The International Food and Agribusiness Management Review. 2016. Vol. 21(3). Pp. 293-316. https://doi.org/10.22434/IFAMR2017.0051.

28. Lupenko Yu. O., Gutorov A. O., Gutorov O. I. Investment Ensuring for Development of Integration Relations in the Agricultural Sector of Ukrainian Economy. Financial and Credit Activity: Problems of Theory and Practice. 2018. Vol. 4. No. 27. Pp. 381-389. https://doi.org/10.18371/fcaptp.v4i27.154221.

29. Onegina V, Husiatynskyi M., Mayorova T., Bohrinovtseva L., Sedikov D. Informational Support of Cash Flow Management Process in Public Administration. International Journal of Innovation Technology and Exploring Engineering (IJITEE). 2019. Vol. 8. Is. 11. Pp. 2836-2841. https://doi.org/10.35940/ijitee.K2401.0981119.

\section{References}

1. Antoshchenkova, V. V. and Kravchenko, O. M. (2016)б Economic efficiency of milk production and sale in Ukraine. Actual problems of innovative economy, no. 3, pp. 39-44. 
2. Bodnar, O. V., Kozak, O. A. and Kopytets, N. H. (2014), The directions of regulation of relations between producers, traders and consumers of socially important food. Ekonomika APK, no. 2, pp. 42-50.

3. Heyets, V. (2016), Ukraine's economy: key problems and prospects. Ekonomika i prohnozuvannia, no. 1, pp. 7-22.

4. Glubish, L. (2015), Theoretical platforms of economic interests groups and concordance them uring market's interaction. Ekonomika ta derzhava, no. 12, pp. 1723.

5. Hrytsenko, A. (2011), Institutional political economy: methodological potential and new opportunities. Formation of market economy. Special issue: Methodological problems of modern political economy, pp. 21-31.

6. Hryshchenko, A. (2011), Integration vector of realization of national economic interests of Ukraine: theoretical and practical aspects. The International Economic Policy, vol. 1-2, pp. 246-274.

7. Dalevska, N. M. (2012), National economic interests of Ukraine in conditions of global competition. Economic Annals-XXI, no. 11-12, pp. 15-18.

8. Demianenko, S. I. (2014), To the problem of the development strategy of agrarian sector of Ukrainian economy. Ekonomika APK, no. 1, pp. 14-19.

9. Zinchuk, T. O. (2008), Yevropeiska intehratsiia: problemy adaptatsii ahrarnoho sektora ekonomiky Ukrainy [European integration: problems of adaptation of the agrarian sector of the Ukrainian economy], DAEU, Zhytomyr, Ukraine.

10. Kyryliuk, Ye. M. (2012), Realization of interests of agrarian market subjects in the economic system of modern Ukraine. Economy of Ukraine, no. 11, pp. 62-75.

11. Kravchenko, O. M. (2017), Harmonization of economic system. Ekonomika $A P K$, no. 11, pp. 51-56.

12. Kravchuk, I. (2018), Organizational support for the creation of the value added of agricultural production. Agricultural and Resource Economics, vol. 4, no. 3, pp. 71-85, available at: http://www.are-journal.com.

13. Krasnorutskyi, O. and Zaitsev, Yu. (2016), Adaptive mechanisms in the competitiveness management systems of agricultural enterprises. Galician economic bulletin, vol. 50, no. 1, pp. 37-46.

14. Malik, M. Y., Shpykuliak, O. H. and Mamchur, V. A. (2018), Institutional formalization for development of family farms in Ukraine. Ekonomika APK, no. 10, pp. 72-85. https://doi.org/10.32317/2221-1055.201810072.

15. Novikova, N. (2015), Directions of state regulation and evaluation of economic interests in the agricultural sector. Investytsiyi: praktyka ta dosvid, vol. 15, pp. $42-44$.

16. Osipova, L. V. (2014), Problems of classification and interaction of interests. Visnyk Khmelnytskoho natsionalnoho universytetu, no. 1, pp. 247-256.

17. Paskhaver, B. Y. (2018), Food self-providing of the population of Ukraine. Ekonomika APK, no. 1, pp. 5-10.

18. Riabokon, V. P. and Novikova, N. L. (2016), Improvement of state regulation of economic interests of agrarian sphere. Ekonomika APK, no. 3, pp. 14- 
20.

19. Smiesova, V. L. (2017), The main stages in the development of the theory of economic interests. Problems of Economy and Political Economy, no. 2, pp. 65-85.

20. Strishenez, O. and Galyant, S. (2018), Institutional Economic Theory: the Scientific and Theoretical Preconditions of Origin (German Historical School). Economic journal of Lesia Ukrainka Eastern European National University, vol. 1, no. 13, pp. 16-21. https://doi.org/10.29038/2411-4014-2018-01-16-21.

21. Semkina, T. (2017), Theoretical approaches to the analysis of the functioning of the subject of entrepreneurial activity. Economics. Management. Business, no. 3, pp. 28-34.

22. Tarasevich, V. N. (2017), On the epistemology of state capitalism. Problems of Economy and Political Economy, no. 4, pp. 59-82.

23. Chorna, O. Yu. and Hlubokova, N. V. (2013), Harmonization of economic interests as a basis for ensuring the economic security of the enterprise. Menedzhment: rozvytok, teoriia ta praktyka. Materialy naukovo-praktychnoi konferentsii [Management: development, theory and practice. Materials of the scientific-practical conference], Sieverodonetsk, Ukraine.

24. Shpykuliak, O. H. (2010), Instytutsii u rozvytku ta rehuliuvanni ahrarnoho rynku [Institutions in development and regulation of the agrarian market], NSC «IAE», Kyiv, Ukraine.

25. Shpychak, O. M. (2017), Analiz potochnoi kon'iunktury i prohnoz rynkiv tvarynnytskoi produktsii $v$ Ukraini [Analysis of the current situation and forecast market of livestock products in Ukraine], NSC «IAE», Kyiv, Ukraine.

26. Canning, P., Weersink, A. and Kelly J. (2016), Farm share of the food dollar: an IO approach for the United States and Canada. Agricultural Economics, vol. 47, pp. 505-512. https://doi.org/10.1111/agec.12250.

27. Cucagna, M. E. and Goldsmith, P. D. (2016), Value adding in the agri-food value chain. The International Food and Agribusiness Management Review, vol. 21(3), pp. 293-316. https://doi.org/10.22434/IFAMR2017.0051.

28. Lupenko, Yu. O., Gutorov, A. O. and Gutorov, O. I. (2018), Investment Ensuring for Development of Integration Relations in the Agricultural Sector of Ukrainian Economy. Financial and Credit Activity: Problems of Theory and Practice, vol. 4, no. 27, pp. 381-389. https://doi.org/10.18371/fcaptp.v4i27.154221.

29. Onegina, V, Husiatynskyi, M., Mayorova, T., Bohrinovtseva, L. and Sedikov D. (2019), Informational Support of Cash Flow Management Process in Public Administration. International Journal of Innovation Technology and Exploring Engineering (IJITEE), vol. 8, is. 11, pp. 2836-2841. https://doi.org/10.35940/ijitee.K2401.0981119. 
How to cite this article? Як цитувати цю статтю?

Стиль - ДСТУ:

Кравченко О. Характерні ознаки, фактори і форми реалізації економічних інтересів учасників ринку продукції тваринництва. Agricultural and Resource Economics. 2020. Vol. 6. No. 1. Pp. 101-122. URL: http://are-journal.com.

Style - Harvard:

Kravchenko, O. (2020), Features, factors and forms of economic interests' implementation of cattle products market participants. Agricultural and Resource Economics, vol. 6, no. 1, pp. 101-122. URL: http://are-journal.com. 